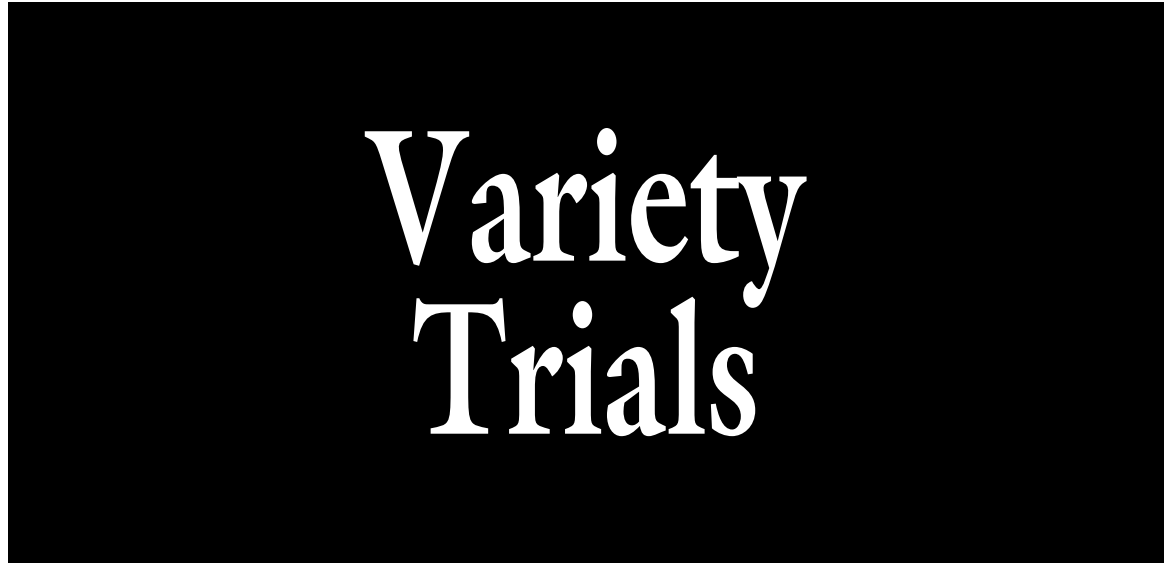

\section{Evaluation of Watermelon Varieties under Organic Production Practices in Georgia}

\author{
George E. Boyhan ${ }^{1,5,9}$, Suzanne O’Connell ${ }^{2,6}$, Ryan McNeill ${ }^{3,7}$, \\ and Suzanne Stone ${ }^{4,8}$
}

AdDitional INDEX WORDs. certified organic production, Citrullus lanatus, $\mathrm{F}_{1}$ hybrids, heirloom open-pollinated, National Organic Program

SUMMARY. Organic production is a fast-growing sector of agriculture in need of variety evaluations under their unique production systems. This study evaluated 16 watermelon (Citrullus lanatus) varieties for their performance characteristics under organic production practices. Plants were grown on plastic mulch-covered beds on land that had been certified organic in accordance with the U.S.

Department of Agriculture National Organic Program. Six of the entries were $F_{1}$ hybrids; the remaining entries were open-pollinated (OP) varieties. Of the 10 OP varieties, three were considered heirloom varieties, including Cream of Saskatchewan, Georgia Rattlesnake, and Moon \& Stars. 'Georgia Rattlesnake' was the highest yielding variety and had the greatest average fruit weight. Along with 'Georgia Rattlesnake', 'Nunhems 800', 'Nunhems 860', 'Orangeglo', and 'SSX 8585' were included in the top five yielding varieties. The top five yielding varieties had fruit size that averaged more than $20 \mathrm{lb}$. Fruit size correlated with rind thickness, with lighter fruit having thinner rind (Pearson's correlation, $r=0.779$ ), which is not unexpected. 'Sangria' had the greatest average soluble solids content at $11.2 \%$, which was greater than all entries with soluble solids less than $10 \%$.

$\overline{\text { Received for publication } 2 \text { Oct. 2018. Accepted for }}$ publication 19 Feb. 2019.

Published online 7 May 2019.

${ }^{1}$ Department of Horticulture, University of Georgia, 1111 Miller Plant Science Building, Athens, GA 30602

${ }^{2} 118$ Swan Quarter Drive, Cary, NC 27519

${ }^{3}$ University of Georgia, Durham Horticulture Farm, 1221 Hog Mountain Road, Watkinsville, GA 30677

${ }^{4} 2416$ Radio City Street, Las Vegas, NV 89135

${ }^{5}$ Professor, Extension Horticulturist-Vegetables.

${ }^{6}$ Former assistant professor.

${ }^{7}$ Farm superintendent.

${ }^{8}$ Former graduate student.

${ }^{9}$ Corresponding author. E-mail: gboyhan@uga.edu.

This is an open access article distributed under the CC BY-NC-ND license (https://creativecommons.org/ licenses/by-nc-nd/4.0/).

https://doi.org/10.21273/HORTTECH04199-18
W

atermelon is an important crop worldwide, with 3.5 million ha produced (Food and Agricultural Organization of the United Nations, 2016). The United States represents just over $1 \%$ of world watermelon production, whereas
China represents more than $50 \%$. In Georgia, almost 8000 ha are produced, with a farm gate value of more than \$124 million (Wolfe and Stubbs, 2016).

Organic and local vegetable production (defined as within 100 miles of sale or consumption) has grown dramatically during the past 20 years (U.S. Department of Agriculture, 2014). There has been a $300 \%$ growth in certified organic production from 2002 to 2015 (U.S. Department of Agriculture, 2016). A survey of Georgia direct-market growers indicated a preference for OP varieties, such as Sugar Baby, Crimson Sweet, and Moon \& Stars (Stone, 2017).

The growth of organic production has resulted in the need for vegetable variety trials under organic conditions. There have been a number of trials evaluating vegetables under organic conditions, but not with watermelons. Organically produced cantaloupe (Cucumis melo) varieties were evaluated for the severity of powdery mildew (Podosphaera xanthii) and downy mildew (Pseudoperonospora cubensis) with two different production methods of a mowed cover crop or the cover crop was tilled in (Marine and Everts, 2016). Tomato (Solanum lycopersicum) was evaluated under organic management practices with 14 entries that included both OP varieties popular with organic growers and $F_{1}$ hybrids used in conventional production, with $\mathrm{F}_{1}$ varieties outperforming OP varieties (Boyhan et al., 2014). In a wide-ranging set of trials, brassicas were evaluated in Kentucky, with trials evaluating mustard (Brassica juncea), kale (Brassica oleracea Acephala group), collards (B. oleracea Acephala group), and arugula (Eruca sativa) (Coolong et al., 2013). Although there were by-year and season interactions, several varieties were identified that performed consistently well.

\begin{tabular}{llll}
\hline $\begin{array}{l}\text { Units } \\
\text { To convert U.S. to SI, } \\
\text { multiply by }\end{array}$ & U.S. unit & SI unit & $\begin{array}{l}\text { To convert SI to U.S., } \\
\text { multiply by }\end{array}$ \\
\hline 0.4047 & acre(s) & $\mathrm{ha}$ & 2.4711 \\
0.3094 & $\mathrm{cup}(\mathrm{s}) / \mathrm{yard}^{3}$ & $\mathrm{~L} \cdot \mathrm{m}^{-3}$ & 3.2316 \\
0.3048 & $\mathrm{ft}$ & $\mathrm{m}$ & 3.2808 \\
3.7854 & $\mathrm{gal}$ & $\mathrm{L}$ & 0.2642 \\
2.54 & inch(es) & $\mathrm{cm}$ & 0.3937 \\
25.4 & inch(es) & $\mathrm{mm}$ & 0.0394 \\
0.4536 & $\mathrm{lb}$ & $\mathrm{kg}$ & 2.2046 \\
1.1209 & lb/acre & $\mathrm{kg} \cdot \mathrm{ha}^{-1}$ & 0.8922 \\
0.0254 & mil(s) & $\mathrm{mm}$ & 39.3701 \\
6.8948 & $\mathrm{psi}$ & $\mathrm{kPa}$ & 0.1450
\end{tabular}


Organic trials are not just important in the United States; other countries are also conducting these trials. In France, 14 research stations have conducted organic variety trials involving 416 varieties with a concentration on salad greens, cauliflower (B. olevacea Botrytis group), belgian endive (Cichorium intybus), and tomato (Porteneuve and Rey, 2008). Franco et al. (2007) evaluated nine fennel (Foeniculum vulgare) and 21 cabbage (B. oleracea Capitata group) varieties in organic trials on an organic farm in Italy. For the fennel varieties, the entries were evaluated for seed production, disease resistance, and physical characteristics. Cabbage varieties were evaluated for head shape, leaf color, earliness, compactness, and head size.

Organic variety trials are the first step in developing new varieties that address specific organic grower needs. For example, the Northern Organic Vegetable Improvement Collaborative aims to evaluate existing varieties and develop new varieties with farmer participation in the breeding process (Myers et al., 2012). The challenges and methods of breeding for organic production have been explored with some unique perspectives (Boyhan and Stone, 2016). These perspectives embrace breeding projects that include growers, chefs, amateur gardeners, and so on, not only in the final evaluation, but also throughout the breeding process. In addition, specific local environments and consumers are to be considered in such breeding efforts.

Several of the varieties in these trials include older varieties, including heirloom varieties, which are those varieties developed during the early part of the 20th century or earlier (DeMuth, 1998). 'Cream of Saskatchewan' is a small heirloom watermelon with 8- to 10-lb fruit and cream-colored flesh. Fruit of this size are often referred to as icebox melons. This variety was brought to North America by Russian immigrants who settled in Saskatchewan, Canada, and is considered adapted to cooler climates (Stone, 2017).

'Moon \& Stars', another heirloom variety, has a unique rind pattern, which is dark green with yellow spots of varying size from less than 1 inch to several inches across. This variety of unknown pedigree developed by a Colorado grower was released by Henderson and Co. in 1926 (Stone, 2017).

'Georgia Rattlesnake' was first introduced around 1870 by M.W. Johnson of Atlanta, GA, and is considered an heirloom variety. It is a large, long melon that is light green with dark-green stripes (Whitaker and Jagger, 1937). 'Jubilee', a variety developed at the Florida Agricultural Experiment Station in Lessburg by J.M. Crall and released in 1963, is now used to define a type of fruit to which 'Georgia Rattlesnake' belongs (Campbell, 1992). 'Jubilee'-type fruit are 25 to $40 \mathrm{lb}$.

Other OP types include 'Sugar Baby', which was first introduced in 1955 and is still widely grown for local markets (Wehner, 2016). It is often used in watermelon breeding as a bioassay variety that is susceptible to all watermelon races of fusarium wilt [Fusarium oxysporum f. sp. niveum (Wehner, 2008)]. 'Sugar Baby' has round fruit that weigh 5 to $15 \mathrm{lb}$. 'Blacktail Mountain' is a variety that is very similar to 'Sugar Baby', producing small dark-green or black fruit. This variety was developed by Glenn Drowns during the 1970s in Idaho (Seed Savers Exchange, 2016). This is a short-season variety that is adapted to cooler environmental conditions.

The Southeastern Vegetable Breeding Laboratory in Charleston, $\mathrm{SC}$, was the source of 'Charleston Gray', which was released in 1954 by C. Fred Andrus (Fery, 2007). The pedigree of this variety was $\{[$ (Africa $8 \times$ Iowa Belle $) \times$ Garrison $] \times$ Garrison $] \times[($ Hawkesbury $\times$ Leesburg $) \times$ Garrison](Stone, 2017). This is a large, long melon (18-25 lb) with a gray (light green) rind that had fusarium wilt, anthracnose (Colletotrichum orbiculare), and sunscald resistance (Wehner, 2016). It was a widely grown OP variety in the southeastern United States that fell out of favor because it was considered more susceptible to bacterial fruit blotch (Acidovorax avenae ssp. citrulli). This apparent greater susceptibility may have more to do with the light-green rind color, which made the infection more apparent than on watermelons with a darker rind.

'Crimson Sweet' is another popular OP variety among organic growers and was developed at Kansas State University as a disease-resistant variety (Hall, 1963). The pedigree of this variety is Miles $\times$ Peacock from which the $\mathrm{F}_{2}$ was crossed with 'Charleston Gray'. 'Crimson Sweet' is the descriptor for varieties of this type, with round fruit of $\approx 25 \mathrm{lb}$ with a lightgreen/dark-green stripe pattern.

'AU-Producer' was an OP developed at Auburn University by J.D. Norton (Norton et al., 1985). This variety was developed from a cross of 'Crimson Sweet' and PI 271778 in a backcross breeding program for disease resistance to race 2 anthracnose, fusarium wilt, and gummy stem blight (Didymella bryoniae).

'Allsweet' was a variety that was developed by C.V. Hall and was released in 1970 with similar disease resistance to 'Charleston Gray', but with better fruit quality. It has resistance to fusarium wilt and tolerance to anthracnose (Hall, 1972). It has a dark-green rind with light-green stripes. It is oblong, about 20 to $25 \mathrm{lb}$, and is the descriptor for this type of watermelon.

'Orangeglo' is a variety that produces large fruit (20-3l lb) with orange flesh (Seed Savers Exchange, 2019). It was believed to be first offered during the 1960s by Willhite Seed Company (Seed Savers Exchange, 2019).

Other varieties developed during the latter half of the 20th century include $\mathrm{F}_{1}$ hybrids with uniform characteristics, disease resistance, and consistent yields. 'Sangria' was developed by T.V. Williams during the 1980s and 1990s and was released as an $\mathrm{F}_{1}$ variety along with 'Mardi Gras' and 'Fiesta' (Gusmini and Wehner, 2005-2006). It has intermediate resistance to anthracnose and Fusarium race 1.

Nunhems Vegetable Seeds (Parma, ID) has developed several modern $\mathrm{F}_{1}$ hybrid watermelon varieties that are grown primarily by conventional growers (Nunhems U.S.A., 2015). 'Premium $\mathrm{F}_{1}$ ' is a diploid variety that has a listed fruit size of 5.5 to $7.5 \mathrm{lb}$. Other Nunhems Vegetable Seed varieties include ' $800 \mathrm{~F}_{1}$ ', which is an oblong watermelon with a dark-green rind and a light-green stripe, averaging 24 to $28 \mathrm{lb}$. ' $860 \mathrm{~F}_{1}$ ' is another Nunhems variety in this fruit category, averaging 20 to $24 \mathrm{lb}$. Finally, '790 $\mathrm{F}_{1}$ ' is also in this class of watermelon, with 22 to $26 \mathrm{lb}$ average fruit weight. All these watermelons are considered Allsweet types.

'SSX 8585' is another Allsweet type $/ F_{1}$ hybrid that was developed and released by Sakata Seed [Morgan 
Hill, CA (Sakata Seed, 2018)]. This variety has 18 - to 22 -lb fruit with resistance to anthracnose and fusarium wilt.

Watermelon is an important crop in Georgia; however, it is not widely grown in organic production. The objective of this study was to evaluate watermelon varieties for their performance under organic production practices in Georgia. This included yield and fruit characteristics of both $\mathrm{F}_{1}$ hybrids and $\mathrm{OP}$ varieties.

\section{Materials and methods}

Field experiments during the 2016 and 2017 seasons were held at the Durham Horticulture Farm in Watkinsville, GA (lat. $33^{\circ} 55^{\prime} \mathrm{N}$, long. $83^{\circ} 25^{\prime} \mathrm{W}$ ) on a Cecil sandy loam (fine, kaolinitic, thermic Typic Kanhapludults). The land was certified by the Georgia Crop Improvement Association under the U.S. Department of Agriculture's National Organic Program.

The field was prepared according to University of Georgia Cooperative Extension Service recommendations (Boyhan and Kelley, 2000). Fertilizer 10N-0.9P-6.6K (10-2-8 All-Season; Nature Safe, Irving, TX) was applied and incorporated at a rate of $180 \mathrm{lb} / \mathrm{a}$ cre nitrogen $(\mathrm{N})$ before final bed preparation. The final bed preparation consisted of applying l-mil white on black plastic mulch (Sigma Plastics Group, Lyndhurst, NJ) with a single drip irrigation line $(8$-inch emitter spacing, $0.2 \mathrm{gal} / \mathrm{h}$ at $10 \mathrm{psi}$ ) (Toro Micro-Irrigation, El Cajon, CA) under the plastic. Beds were $\approx 6$ inches high and 30 inches across the top on 6 -ft centers.

Watermelon seed was sown in the greenhouse on 31 Mar. 2016 and 3 Apr. 2017. The media used included organic potting soil (Fafard Natural \& Organic Potting Soil; Fafard, Agawam, MA) mixed with compost, worm castings, and perlite in about equal amounts. To this was added 3 cups $/$ yard $^{3}$ of kelp meal (Espoma Co., Millville, NJ), greensand (Fertrell Co., Bainbridge, PA), gypsum (Oldcastle Lawn \& Garden, Atlanta, GA), bone meal (Voluntary Purchasing Group, Bonham, TX), and 1 cup/yard 3 blood meal (Voluntary Purchasing Group). Seedlings were transplanted to the field on 3 May 2016 and 2 May 2017. Stand count was recorded on 2 June 2016 and 25 May 2017.

No insecticides or fungicides were used during these trials. Weed control in 2016 included hand weeding and spreading pine (Pinus sp.) needles in the tractor wheel rows between beds.
In 2017, weed control involved hand weeding only.

In 2016, watermelons were harvested and processed three times on 12, 20-22, and 25-28 July 2016. In 2017, watermelon were harvested and processed 10-12 July 2017. All fruit were weighed and counted for each experimental unit. In 2016, two representative fruit from each experimental unit were individually weighed, cut longitudinally, and measured for length (stem end to blossom end), width (perpendicular to length), and rind thickness [outside fruit edge to fruit flesh (i.e., color change for specific fruit)]. In addition, the soluble solids of the central tissue were measured with a refractometer (Spectrum Technologies, Plainfield, IL) and fruit firmness was measured twice with a penetrometer (Certified Material Testing Products, Palm Bay, FL) with an 8-mm probe in the central portion of the fruit. In 2017, the same measurements were recorded except for individual fruit weight.

There were 16 entries in these trials, with an experimental design of a randomized complete block design of four replications. Each experimental unit consisted of 10 plants arranged with 6-ft between-row spacing and an in-row spacing of $4 \mathrm{ft}$. Data collected

Table 1. Organic watermelon trial results of fruit type, yield, fruit weight, and fruit characteristics held at Watkinsville, GA, in 2016-17.

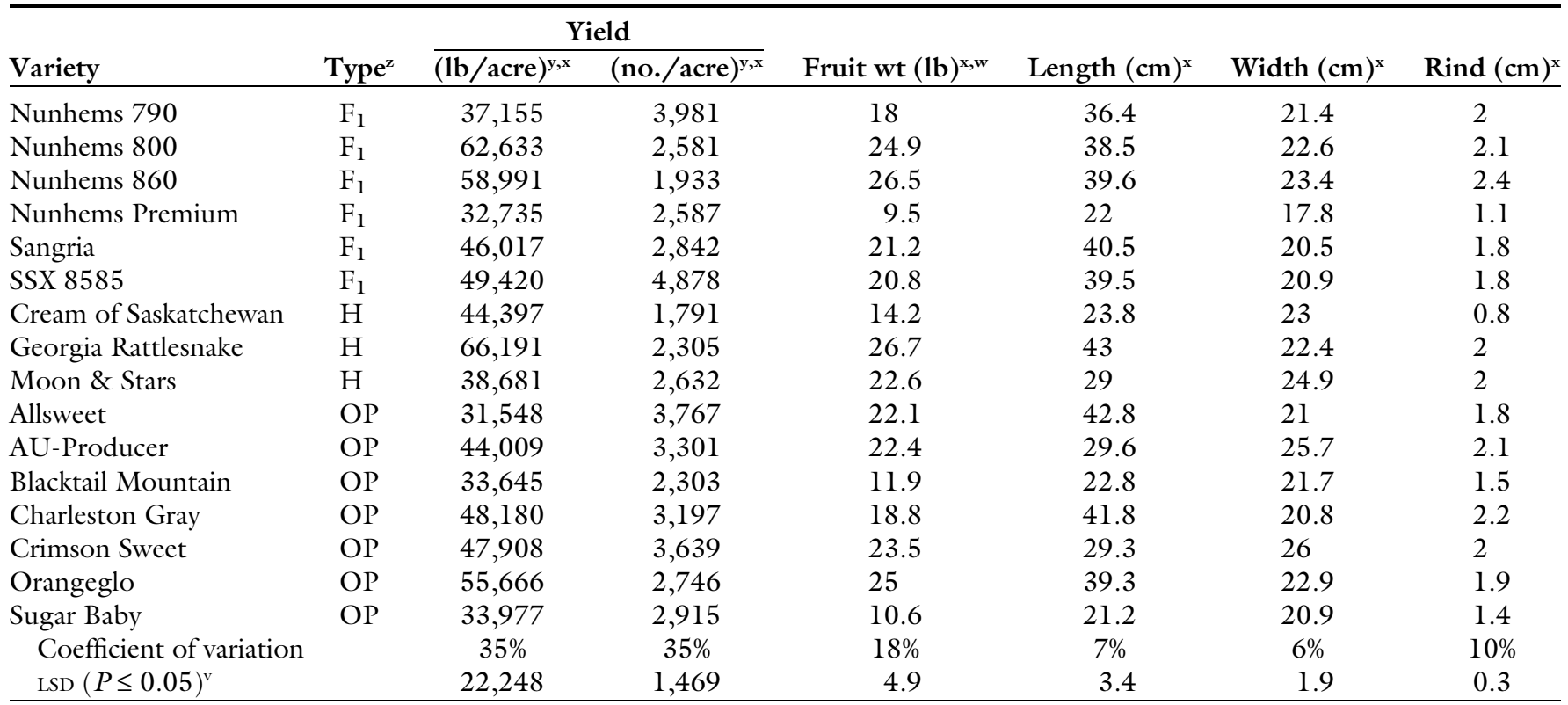

${ }^{\mathrm{z}} \mathrm{OP}=$ open pollinated; $\mathrm{H}=$ heirloom open-pollinated varieties developed during the early part of the 20 th century or earlier; $\mathrm{F}_{1}=\mathrm{F}_{1}$ hybrid.

${ }^{\mathrm{y}}$ Marginal means reported.

${ }^{\mathrm{x}} \mathrm{l} \mathrm{lb} /$ acre $=1.1209 \mathrm{~kg} \cdot \mathrm{ha}^{-1}, \mathrm{l}$ fruit $/$ acre $=2.471 \mathrm{l}$ fruit $/ \mathrm{ha}, \mathrm{l} \mathrm{lb}=0.4536 \mathrm{~kg}, \mathrm{l} \mathrm{cm}=0.3937$ inch

wAnalysis based on individual fruit weighed in 2016 only.

${ }^{\vee}$ Fisher's protected least significant difference (LSD). 


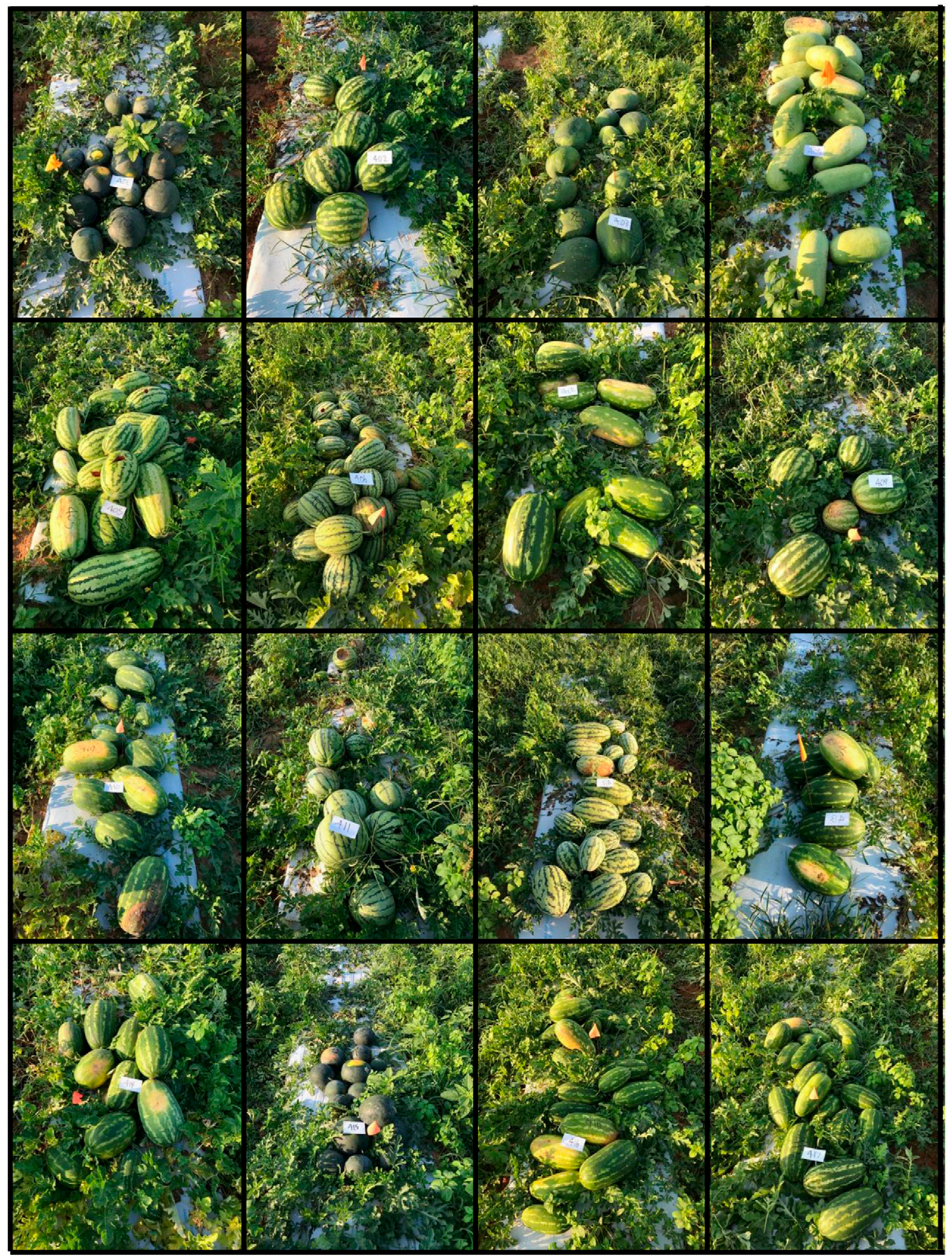

Fig. 1. Varieties of watermelon fruit immediately after harvest. The first row includes 'Sugar Baby', 'Crimson Sweet', 'Moon \& Stars', and 'Charleston Gray'. The second row includes 'Georgia Rattlesnake', 'Nunhems Premium', 'Allsweet', and 'AUProducer'. The third row includes 'Nunhems 860', 'Cream of Saskatchewan', 'Orangeglo', and 'Nunhems 790 hq'. The fourth row includes 'Nunhems 800', 'Blacktail Mountain', 'Sangria', and 'SSX 8585'. The white card in each image is $4 \times 6$ inches $(10.2 \times 15.2 \mathrm{~cm})$. 
from each experimental unit were extrapolated to pounds per acre before analysis. Yield data were analyzed with Stata 15.1 (Stata Corporation, College Station, TX). An analysis of covariance was calculated for yield that used stand count as the covariate. Because of this, the marginal means are reported rather than the arithmetic means, which adjust the means based on the regression of the stand count covariate (Boyhan, 2013). In addition, single df comparisons of $\mathrm{OP}$ and $\mathrm{F}_{1}$ hybrids as well as OP and heirlooms were calculated.

\section{Results and discussion}

Of the 10 OP varieties, three were considered heirloom varieties. In general, conventional commercial watermelon production is dominated by $\mathrm{F}_{1}$ hybrids and, in recent years, seedless watermelons have come to dominate this market (Kemble, 2018). Organic growers, particularly in the southeastern United States, are interested in serving local markets and growing well-known varieties for these markets. This market niche is dominated by OP varieties and, particularly, heirloom varieties, which by definition refer to seeded varieties.

There was no by-year interaction for yield or fruit characteristics, so results were combined for both years, nor was year by itself a significant factor. The highest yielding variety was 'Georgia Rattlesnake' with 66,191 lb/acre, which did not differ from 'AU-Producer' with 44,009 lb/acre (Table 1 ). In addition, 'Georgia Rattlesnake' had the greatest fruit weight at $26.7 \mathrm{lb}$, which was $26 \%$ greater than 'Sangria' at $21.2 \mathrm{lb}$. It has been noted that overall yield in watermelon is often associated with fruit size. In conventional watermelon production in Georgia, average yields are about $40,000 \mathrm{lb} / \mathrm{acre}$ (Boatright and McKissick, 2010; Boyhan and Granberry, 2000; Boyhan and Kelley, 2000). Although these average yields are used for budgeting, trial yields and grower reports indicate that yields can be much greater than this.

The larger the individual fruit size, the greater the yield (Kumar and Wehner, 2011). In this particular case, Pearson's correlation between mean fruit weight and mean yield was 0.674 . There was no difference in yield when comparing the aggregate of OP varieties to $\mathrm{F}_{1}$ hybrids $(P=0.318)$. The three OP heirloom varieties yielded more than the other OP varieties $(P=$ 0.049 ). The aggregate of the heirloom varieties yielded $50,55 \mathrm{l} \mathrm{lb} /$ acre compared with $41,594 \mathrm{lb} /$ acre for the other OP varieties. The greater yield is probably because two of the three heirlooms, 'Moon \& Stars' and 'Georgia Rattlesnake', have relatively large fruit -22.6 and $26.7 \mathrm{lb}$, respectively.

The number of fruit per acre differed significantly between the entries. 'SSX 8585' had the greatest number of fruit per acre, with 4878 fruit/acre. This was significantly greater than 'AUProducer', with 3301 fruit/acre. The least fruit per acre included varieties that had relatively small fruit, such as 'Cream of Saskatchewan' and 'Blacktail Mountain', as well as varieties that produced larger fruit, such as 'Nunhems 860' and 'Georgia Rattlesnake'. It is unclear why this is so with the smaller entries, but with the varieties with larger fruit it makes sense that there would be fewer fruit because the plants put more resources into each individual fruit.

Rind thickness has implications on fruit quality. First, the thicker the rind, the more resistant to breakage; however, from an aesthetic perspective, a thinner rind is generally considered better. The smallest fruit were 'Nunhems Premium', 'Sugar Baby', 'Blacktail Mountain', and 'Cream of Saskatchewan', which in general had thin rinds. There was a correlation between fruit size and rind thickness. Smaller fruit, not unexpectedly, had thinner rinds, with a Pearson's correlation of 0.697 between these characteristics.

Table 2. Organic watermelon fruit quality characteristics of flesh color, soluble solids, and flesh firmness in $2016-17$.

\begin{tabular}{|c|c|c|c|c|}
\hline Variety & Color $^{\mathrm{z}}$ & Color rating $(1-5 \text { scale })^{\mathrm{y}}$ & Soluble solids (\%) & Firmness $(p s i)^{x}$ \\
\hline AU-Producer & Pink & 2.4 & 10.6 & 1.5 \\
\hline Charleston Gray & Pink & 2.9 & 9.2 & 1.5 \\
\hline Cream of Saskatchewan & White & 3.8 & 9.9 & 1 \\
\hline Crimson Sweet & Pink & 3.4 & 11.1 & 1.3 \\
\hline Nunhems 790 hq & Pink/red & 2 & 10.3 & 2.1 \\
\hline Nunhems 800 & Pink & 2.5 & 10.9 & 1.4 \\
\hline Nunhems 860 & Pink/red & 1.8 & 9.6 & 1.7 \\
\hline Nunhems Premium & Red & 4.5 & 10.7 & 1.7 \\
\hline Orangeglo & Orange & 4.4 & 11 & 1.1 \\
\hline LSD $(P \leq 0.05)^{\mathrm{w}}$ & & 1.2 & 0.9 & 0.5 \\
\hline
\end{tabular}

${ }^{\mathrm{z}}$ Each fruit examined was identified by color: red, pink, yellow, white, or orange. Some varieties had fruit that were either designated as red or pink and, in such cases, both colors are listed, with the first color indicating the majority of fruit.

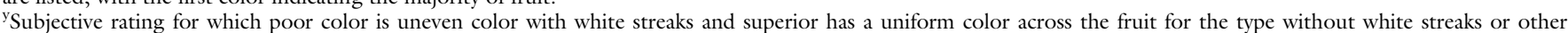
imperfections. $l=$ poor; $5=$ superior.

${ }^{x}$ Penetrometer, with an 8 -mm $(0.31$-inch $)$ probe, with two measurements for each fruit. 1 psi $=6.8948 \mathrm{kPa}$.

wFisher's protected least significant difference (LSD). 
The ratio of the length and width (length/width) gives an indication of the shape of the fruit. Ratio values at or near one indicate a round or nearly round fruit, whereas larger ratios (1.7-2.0) indicate oblong fruit. Figure 1 shows the fruit from each entry in these trials. The white card on each group of fruit is a $4 \times 6$-inch card to give perspective.

Most of the fruit in this study had pink or red flesh (Table 2 ). The two varieties with different flesh colors included Cream of Saskatchewan, which had white flesh, and Orangeglo, which had orange flesh.

The best color rating was for 'Nunhems Premium,' with a rating of 4.5 on a 1 - to 5 -point rating scale. The only other variety with a rating greater than four was 'Orangeglo', with 4.4. 'Nunhems Premium' had an intense red color and 'Orangeglo' had a bright orange color, both of which were rated as desirable characteristics.

The U.S. Department of Agriculture grade standards for watermelon with "very good internal quality" require a minimum soluble solids content of $10 \%$ (U.S. Department of Agriculture, 2006). Ten of the 16 varieties averaged more than $10 \%$ soluble solids (Table 2). 'Sangria' had the greatest soluble solids content at $11.2 \%$, which was better than any variety with less than $10 \%$ soluble solids.

The firmest fruit was seen in 'Nunhems 790 hq', at 2.1 psi, which was better than any entry with a firmness less than 1.6 psi. Although there were differences in fruit firmness, the use of the penetrometer can often be influenced by the operator. A method that removes human influence on this measurement would be more reliable, so caution should be exercised when interpreting these results.

In conventional watermelon production with plastic mulch and drip irrigation, part of the fertilizer is applied preplant and the remainder is applied by fertigation. Unfortunately, water-soluble organic fertilizers that can be readily applied through a drip system are either not available or require agitation to apply because they are not truly water soluble; therefore, all fertilizer was applied before final bed preparation. In Georgia, on the Piedmont soils of north Georgia, the maximum amount of recommended $\mathrm{N}$ is $120 \mathrm{lb} /$ acre. We applied $180 \mathrm{lb} /$ acre $\mathrm{N}$ because organic fertilizer has to undergo mineralization before the nutrients are available for plant growth; therefore, to compensate for this, additional fertilizer was applied. Preplant application of all the fertilizer under the plastic mulch worked very well based on yields that were comparable to other watermelon trials, and it has been shown to work in other crops such as onion [Allium cepa (Boyhan, 2007; Coolong, 2015)].

Weed control is a major problem in organic production, particularly in the southeastern United States. The mild winters and long growing season ensures an abundance of weeds. Plastic mulch is particularly helpful in controlling weeds; however, weeds continue to be a problem in the row middles and in the planting holes. To help with this problem, pine needles were spread in the row middles in 2016. This has shown some limited success in other crops, particularly onion (Boyhan et al., 2006). However, it did not provide season-long weed control. In fact, it ultimately interfered with hoeing, particularly where the plastic mulch edges were buried at the wheel row. Because of this, this practice was abandoned for the 2017 growing season. Effective weed control is a challenge in organic production and will continue to hinder growth in this sector particularly as production increases.

There are many watermelon varieties from which to choose for organic growers. Most organic growers in Georgia have relatively small holdings, so watermelons may not be the ideal vegetable choice because of their vining habit and space requirements. This will probably change as demand for organic produce increases. Small-fruited types such as 'Nunhems Premium', 'Cream of Saskatchewan', 'Blacktail Mountain', and 'Sugar Baby' may be best, because these varieties have more fruit per vine than larger fruited types. Interesting rind patterns, different flesh colors, and interesting historical backgrounds may be the most desirable for local organic markets. For growers wishing to save seed, $\mathrm{F}_{1}$ hybrids would not be suitable because they do not breed true to type. Although not evaluated in this study, seedless watermelons are also available for smallscale organic growers, but because of additional care-particularly during germination and the need for pollinizer plants-they may not be the optimal choice for these organic growers. Further work on watermelon variety development, such as plants with a smaller footprint (e.g., short-internode types), improved disease resistance (particularly with heirloom types), and highquality fruit are needed for organic growers. In conclusion, this study gives growers information they can use to select an appropriate variety for which they have to balance characteristics such as yield, fruit size, and fruit characteristics.

\section{Literature cited}

Boatright, S.R. and J.C. McKissick. 2010. 2009 Georgia farm gate vegetable report. Univ. Georgia Annu. Rpt. AR 10-32.

Boyhan, G. 2007. Organic Vidalia onion production. Univ. Georgia Coop. Ext. Serv. Circ. 913.

Boyhan, G. and D.M. Granberry (eds.). 2000. Commercial watermelon production. Univ. Georgia Coop. Ext. Serv. Bul. 996.

Boyhan, G.E. 2013. Agricultural statistical data analysis using Stata. CRC Press, Boca Raton, FL.

Boyhan, G.E., R. Hicks, and C.R. Hill. 2006. Natural mulches are not very effective for weed control in onions. HortTechnology 16:523-526.

Boyhan, G.E. and W.T. Kelley. 2000. Commercial watermelon production. Univ. Georgia Coop. Ext. Serv. Bul. 996.

Boyhan, G.E. and S.P. Stone. 2016. Breeding for organic and sustainable production, p. 123-136. In: D. Nandwani (ed.). Organic farming for sustainable agriculture. Springer, Cham, Switzerland

Boyhan, G.E., S. Tate, R. McNeill, and J. McConnaughey. 2014. Evaluation of tomato varieties under organic production practices in Georgia. HortTechnology 24:253-258.

Campbell, R. 1992. Melon expert retires, heart still in field. 22 Mar. 2018. <http:// articles.orlandosentinel.com/1992-0122/news/9201220530_1_melons-crallcrimson-sweet>.

Coolong, T. 2015. Seedless watermelon variety evaluation: 2014. 2014/2015 Vegetable crop variety trial and research report. Univ. Georgia Annu. Publ. 115:61-69.

Coolong, T., D.M. Law, J.C. Snyder, B. Rowell, and M.A. Williams. 2013. Organic leafy greens variety trials in Kentucky: Identifying superior varieties for small-scale organic farmers. HortTechnology 23:241-246. 
DeMuth, S. 1998. Vegetables and fruits: A guide to heirloom varieties and communitybased stewardship. U.S. Dept. Agr., Agr. Res. Serv. SRB 98-05.

Fery, R.L. 2007. Reported death C. Fred Andrus. HortScience 42:1500.

Food and Agricultural Organization of the United Nations. 2016. Crop production database. 14 Feb. 2018. <http://www. fao.org/faostat/en/\#data/QC>.

Franco, G., C. Cattivello, and R. Danielis. 2007. Prove varietali in conduzione biologica su orticole autunnali. [Variety trials in conditions of organic farming with autumn vegetables.] Not. ERSA 20:11-13.

Gusmini, G. and T.C. Wehner. 2005-2006. Milestones in watermelon cultivar development. Cucurbit Genetics Coop. Rpt. 2829:62-65.

Hall, C. 1972. High-sugar, high-quality melon released. Amer. Veg. Grower. 20(11):24.

Hall, C.V. 1963. Crimson sweet a new disease resistant watermelon. Kansas State Univ. Agr. Appl. Sci. Circ. 389.

Kemble, J.M. (eds.). 2018. Southeastern U.S. 2018 vegetable crop handbook. Meister Media, Willoughby, $\mathrm{OH}$.

Kumar, R. and T.C. Wehner. 2011. Inheritance of fruit yield in two watermelon populations in North Carolina. Euphytica 182:275-283.

Marine, S.C. and K.L. Everts. 2016. Evaluation of organically produced melon cultivars for powdery and downy mildew severity in Maryland, U.S.A. Cucurbitaceae 2016, XIth Eucarpia Mtg. Cucurbit Genet. Breeding, 24-28 July 2016, Warsaw, Poland.

Myers, J., L. McKenzie, M. Mazourek, W. Tracy, A. Shelton, and J. Navazio. 2012. Breeding peas, sweet corn, broccoli, winter squash, and carrots as part of the Northern Organic Vegetable Improvement Collaborative (NOVIC), Strengthening Community Seed Systems. Proc. Organic Seed Growers Conf. p. $44-45$.

Norton, J.D., R.D. Cosper, D.A. Smith, and K.S. Rymal. 1985. AU-Jubilant \& AU-Producer quality, disease-resistant watermelon varieties for the South. Auburn Univ. Agr. Expt. Sta. Circ. 280.

Nunhems, U.S.A. 2015. Strength in Nunhems watermelon catalog. Nunhems USA, Parma, ID.

Porteneuve, C. and F. Rey. 2008. Agriculture biologique: Le criblage des variétés de légumes. Centre Technique Interprofessionnel des Fruits et Légumes 247:8-12.

Sakata Seed. 2018. SSX8585 (hybrid). 22 Mar. 2018 . <http://www. sakatavegetables.com/vegetable/ Watermelon-All/Watermelon-AllsweetCitrullus-SSX8585-Hybrid>.

Seed Savers Exchange. 2016. Watermelon, Blacktail Mountain. 22 Mar. 2018. <https://www.seedsavers.org/blacktailmountain-organic-watermelon $>$.
Seed Savers Exchange. 2019. Orangeglo watermelon. 7 Jan. 2019. <https://www. seedsavers.org/orangeglo-watermelon $>$.

Stone, S.P. 2017. Using plant breeding, cultivar evaluation, and cultivation strategies to address challenges in sustainable watermelon production. Univ. Georgia, Athens, PhD Diss.

U.S. Department of Agriculture. 2006. United States standards for grades of watermelons. 14 Feb. 2019. <https://www. ams.usda.gov/grades-standards/ watermelon-grades-and-standards $>$.

U.S. Department of Agriculture. 2014. Census of agriculture: Organic survey. 6 Feb. 2019. <https://www.nass.usda. gov/Surveys/Guide_to_NASS_Surveys / Organic_Production $/>$.

U.S. Department of Agriculture. 2016. USDA reports record growth in U.S. organic producers. 6 Feb. 2019. <https:// www.usda.gov/media/press-releases/ $2016 / 04 / 04 /$ usda-reports-recordgrowth-us-organic-producers $>$.

Wehner, T.C. 2008. Watermelon, p. 381418. In: J. Prohens and F. Nuez (eds.). Vegetables I Asteraceae, Brassicaceae, Chenopodicaceae, and Cucurbitaceae. Springer Science, New York, NY.

Wehner, T.C. 2016. Cucurbit breeding at North Carolina State. 21 Mar. 2018. $<$ http://cucurbitbreeding.com/watermelonbreeding $/>$.

Whitaker, T.W. and I.C. Jagger. 1937. Breeding and improvement of cucurbits, p. 207-232. In: Yearbook of agriculture. U.S. Department of Agriculture, Washington, DC.

Wolfe, K. and K. Stubbs. 2016. 2015 Georgia farm gate value report. Univ. Georgia Ctr. Agribusiness Econ. Dev. AR-16-01. 